\title{
Falsos amigos, czyli polsko-hiszpańska homonimia międzyjęzykowa
}

Agata Zamorska | Wydział Filologiczny, Uniwersytet Gdański

\section{Streszczenie}

Słowa kluczowe:

homonimia międzyjęzykowa, fałszywi przyjaciele, falsos amigos, pułapki językowe

Artykuł stanowi opis zjawiska homonimii międzyjęzykowej ujawniającego się w dwu różnych systemach językowych - polskim i hiszpańskim. Polsko-hiszpańskie pary homonimiczne określane są jako fałszywi przyjaciele (hiszp. falsos amigos) ze względu na często implikowane pomyłki językowe i nieporozumienia komunikacyjne. Zjawisko to ukazano na materiale konkretnej grupy słów, których brzmienie lub pisownia są na tyle podobne, że niewprawny użytkownik języka może uważać je za wyrazy spokrewnione ze sobą oraz semantycznie zbieżne. Przy klasyfikacji zebranego słownictwa zastosowano kryteria podziału homonimów zaproponowane przez Małgorzatę Majewską.

\section{Falsos amigos: interlingual homonymy in Polish and Spanish}

\section{Abstract}

The article presents the phenomenon of interlingual homonimy between the Polish and Spanish language systems. The homonymic pairs are commonly called false friends (Span. falsos amigos) because they tend to cause certain linguistic errors and misunderstandings. The author presents this phenomenon based on the chosen words whose pronunciation and spelling are similar enough to be considered by an inexpert speaker as words with common etymology and meaning. The analyzed words have been divided according to the classification criteria for the homonyms proposed by Małgorzata Majewska. 


\section{Wstęp do badań nad homonimią}

Do badań nad zjawiskiem homonimii międzyjęzykowej punktem wyjścia powinna być homonimia jako taka oraz jej odróżnienie od zjawisk powiązanych - homofonii i homografii. W Podręcznym słowniku terminów literackich Michała Głowińskiego (1993: 112) homonimy (gr. homós 'jednakowy' + ónoma 'imię, nazwa') definiowane są na trzy sposoby. W znaczeniu węższym rozumie się je jako "wyrazy jednakowo brzmiące i pisane, ale nie spokrewnione etymologicznie i różnoznaczne". Za przykład Głowiński podaje takie słowa jak para ('dwoje ludzi' lub 'woda w stanie gazowym') oraz drogi (liczba mnoga od słowa droga oraz 'cenny'). W szerszym ujęciu homonimami mają być - zdaniem Głowińskiego (1993: 112) - również:

[...] wyrazy jednakowo brzmiące i pisane, o wspólnym pochodzeniu, których znaczenia tak się zróżnicowały, że ich pokrewieństwo jest słabo uświadamiane, np. klucz (do drzwi), klucz (posiadłość ziemska), klucz (znak muzyczny), klucz (żurawi).

Powyższe pojmowanie homonimii jest tożsame z zakresem znaczeniowym pojęcia homonimii monogenetycznej. Zjawisko to powstaje na skutek rozpadu znaczeniowego danego wyrazu (Buttler 1988: 4). Za przykład może posłużyć również słowo pokój rozumiane jako 'pomieszczenie mieszkalne' oraz jako 'czas bez wojen'. Do XVIII wieku uważano to słowo za polisem, którego obydwa znaczenia odwołują się do 'spokojnego, zacisznego miejsca'.

Głowiński (1993: 112) wyróżnia dodatkowo najszersze znaczenie omawianego pojęcia, w którym homonimami są wszelkie wyrazy polisemiczne. W definicji tej zaciera się całkowicie różnica między homonimią a polisemią, którą z reguły rozumie się jako zjawisko polegające na wieloznaczności motywowanej historycznie (gdy wszystkie znaczenia odwołują się do wspólnego źródła słowa). Tymczasem Słownik języka polskiego pod redakcją Witolda Doroszewskiego (Doroszewski, red., 1958-1969) zawiera następujące wyjaśnienie analizowanego pojęcia: „identyczność brzmienia i pisowni wyrazów mających różne znaczenia i zwykle też różne pochodzenie". Cytowana definicja bliska jest wąskiemu pojmowaniu homonimii ze słownika Głowińskiego. Podobnie homonim rozumiany jest w Encyklopedii popularnej PWN (Krupa, red., 1999: 303): „Wyraz mający jednakowe brzmienie z innym wyrazem, lecz różniący się pochodzeniem, znaczeniem, często też pisownią, np. kosa 'warkocz' i 'narzędzie do koszenia".

Homonimia pozwala zatem na identyczność brzmieniową wyrazów przy ich odmiennej ortografii, przy czym istotna jest również etymologia wyrazów, ponieważ ich podobieństwo formalne musi być przypadkowe. Słowo kosztować może oznaczać zarówno próbowanie potrawy, jak i wskazywać na cenę przedmiotu, przy czym między tymi znaczeniami nie można wskazać żadnej relacji etymologicznej. Tymczasem znaczenia słowa dom jako 1. 'budynek przeznaczony na mieszkania lub zakłady pracy', 2. 'mieszkanie lub pomieszczenie, w którym się mieszka', 3. 'rodzina, domownicy' lokują się na tyle blisko siebie, że można byłoby uznać je za polisem. Problem ten jest 
jednak dużo bardziej skomplikowany w przypadku słowa zamek. Z jednej strony leksem można uznać za polisem, ponieważ zarówno 'budynek warowny', jak i 'zamek błyskawiczny' mają wiele wspólnego z czynnością zamykania, więc poszczególne znaczenia tego wyrazu łączy wspólna etymologia. Z drugiej jednak strony 'zamek błyskawiczny', 'zamek w drzwiach' i 'zamek jako budynek' możemy traktować jako trzy odrębne słowa, bo ich znaczenia są dość od siebie odległe. Jednoznaczne stwierdzenie, czy wyraz ten jest przykładem homonimii, czy polisemii, jest kwestią dyskusyjną.

W obrębie homonimii wyróżnić można homografię (homografy bywają czasem nazywane homogramami), która zakłada tożsamość form nie tylko w brzmieniu, ale również w pisowni. Istnieją też homoformy, czyli wyrazy, które brzmią identycznie tylko w niektórych formach (mogą mieć identyczną formę w jednym z przypadków, ale w pozostałych odmieniać się już inaczej lub mieć inną postać w liczbie mnogiej, np. oko (ludzkie) oraz oko (w rosole) w liczbie mnogiej to już oczy i oka). Trzecim typem homonimii jest homofonia, która obejmuje wszystkie jednostki identyczne pod względem brzmienia bez względu na ich pisownię, np. morze i może. Małgorzata Majewska (2002: 29) zauważa, że relacja nadrzędności pomiędzy homonimią a homofonią nie jest bynajmniej łatwa do rozstrzygnięcia.

Możemy wyróżnić różne typy homonimów, w tym na poziomie wewnątrzjęzykowym:

a. homonimię morfemów, czyli formalną zbieżność dwu znaczeniowo odrębnych morfemów, np. człon radio- może wskazywać na związek z promieniowaniem (np. radioaktywny) lub z radiem (np. radioodbiornik);

b. homonimię leksykalną, czyli formalną zbieżność dwu znaczeniowo odrębnych wyrazów w obrębie jednego języka, np. bal 'pień' i 'zabawa';

c. homonimię frazeologiczną, czyli formalną zbieżność dwu związków wyrazowych, z których jeden jest zespoleniem luźnym, drugi natomiast stanowi związek frazeologiczny, np. wyrażenie Tu jest pies pogrzebany może oznaczać 'o to właśnie chodzi' lub być rozumiane dosłownie jako stwierdzenie o miejscu zakopaniu martwego psa;

d. homonimię składniową, czyli formalną zbieżność dwu struktur składniowych, w których na różne sposoby wytyczać można granicę grup syntaktycznych, co pociąga za sobą zmianę znaczenia, np. gdzie się dzieli? oraz gdzie siedzieli?

Homonimia może istnieć również na poziomie międzyjęzykowym. Jest to formalna zbieżność dwu znaczeniowo odrębnych wyrazów w obrębie różnych języków (Wojan 2010: 268), np. karma w sanskrycie oznacza sumę działań człowieka, a w języku polskim pożywienie. Homonimia międzyjęzykowa rządzi się bardzo podobnymi prawami jak homonimia leksykalna. Choć istnieją pewne powiązania, to też należy zauważyć dzielące oba zjawiska różnice. Niemieckie Balken w znaczeniu pnia drzewa zostało zaadaptowane $w$ języku polskim przy pewnej zmianie w grafii i wymowie i stanowi obecnie homonim leksykalny w stosunku do słowa bal pochodzącego 
z języka francuskiego, w którym oznacza zabawę taneczną. Przy porównaniu np. języka polskiego i francuskiego w kontekście słowa bal nie możemy mówić więc o homonimii międzyjęzykowej, a ponieważ słowo to zostało zapożyczone, zbieżność formalna nie jest zjawiskiem przypadkowym.

Małgorzata Majewska (2002: 56) konstatuje, że w przypadku homonimii międzyjęzykowej powinno się mówić raczej o tożsamości brzmienia (homofonia) niż pisowni (homografia) z uwagi na różnice w systemach fonetycznych różnych języków (jeśli porówna się język polski z rosyjskim z punktu widzenia homografii, to nie znajdzie się stosownych przykładów, co jest powodowane odmiennością alfabetów, natomiast homofonów w obu systemach jest sporo).

Jak zauważa Krzysztof Kusal (2002: VIII), zarówno samo definiowanie homonimii, jak i ustalenie granicy pomiędzy homonimią a polisemią, a także klasyfikacja homonimów są w literaturze przedmiotu traktowane niejednolicie i trudno znaleźć opracowanie, w którym powyższa kwestia byłaby rozwiązana jednoznacznie. Do kwestii nierozwikłanych w zakresie definiowania homonimów należą pytania: 1. które cechy planu wyrażania i planu treści są kluczowe przy ustaleniu homonimii?, 2. czy do homonimów - poza leksemami - można zaliczać również inne jednostki języka?, 3. jakie jest miejsce i status homonimów wewnątrzjęzykowych w systemie języka? (por. Kusal 2002).

Oddzielnie analizować można zjawisko tak zwanej homonimii homonimii, polegające na współwystępowaniu w różnych językach par homonimów leksykalnych, o podwójnym znaczeniu w obu językach, np. polski boj to 'lęk' lub 'boja", a rosyjski boj (6oŭ) to 'bitwa' i 'chłopiec hotelowy' (Buttler 1989: 100-101). Niektóre z tych znaczeń zazębiają się, inne zaś są całkowicie odmienne. Zjawisko to we współczesnej polskiej literaturze przedmiotu bywa określane jako międzyjęzykowa homonimia wewnętrzna (Wojan 2005: 33).

\section{Homonimia międzyjęzykowa jako problem tłumacza}

Ten specyficzny rodzaj homonimów występujących między dwoma systemami językowymi K.F. Rudolf (2004: 5) nazywa pułapkami językowymi, zaznaczając przy tym, że

[...] we wszystkich językach występują wyrazy bardzo podobne, których znaczenia diametralnie się od siebie różnią (co jest prostsze) albo różnią się bardzo nieznacznie (co jest nieco bardziej skomplikowane) i świadomość istnienia tych pułapek ma ogromne znaczenie.

Homonimy międzyjęzykowe nazywa się często fałszywymi przyjaciółmi (również w języku hiszpańskim: falsos amigos), ponieważ osoba niewprawnie posługująca się językiem obcym może podobieństwo brzmieniowe dwóch wyrazów uznać za wystarczający dowód na to, że ich znaczenie również jest podobne. Niewątpliwie tego rodzaju 
pomyłki często utrudniają komunikację, a w najgorszym przypadku kończą się kompromitacją mówiącego (Rudolf 2003: 5). Wspomniany badacz w swoich rozważaniach skupił się na zjawisku homonimii występującym pomiędzy językiem polskim i angielskim, tworząc na potrzeby polskiego użytkownika słownik "wyrazów zdradliwych”, które mogą być problematyczne w użyciu ze względu na podobieństwo do słów polskich o całkowicie lub częściowo innym znaczeniu.

Wśród synonimicznych określeń fałszywych przyjaciół, które jest pojęciem metaforycznym, nie zaś terminem stricte lingwistycznym, możemy znaleźć paronimy międzyjęzykowe, ekwiwalenty pozorne (lub pseudoekwiwalenty), tautonimy, wyrazy zdradliwe (złudne) oraz aproksymaty (Kusal 2002: VIII). Badacz definiuje je następująco: „Homonimy międzyjęzykowe wyrażają stosunek dwóch leksemów o ekwiwalentnej formie (o prawie identycznym lub podobnym brzmieniu) i nieadekwatnej treści".

Pary homonimiczne powstają zazwyczaj wskutek przypadkowej zbieżności fonicznej oraz historycznie uwarunkowanych międzyjęzykowych paralel fonetycznych. Tu Kusal (2002: IX) tworzy rozróżnienie między klasycznie pojmowanymi homonimami międzyjęzykowymi a paronimami międzyjęzykowymi, które stanowią przypadki częściowego podobieństwa fonetycznego (i morfologicznego), uwarunkowanego wspólnotą genetyczną omawianych par wyrazów, całkowicie lub częściowo zróżnicowanych pod względem znaczeniowym.

Odmiennym rozróżnieniem posługuje się Katarzyna Wojan (2010: 274-275), która terminu homonimy międzyjęzykowe używa zamiennie z terminem paronimy i przeciwstawia go pojęciu fałszywych przyjaciół. W pierwszej kategorii mielibyśmy do czynienia $z_{\text {" }}$ relacjami semantyczno-leksykalnymi leksemów przynależnych do dwóch języków o zbieżnej formie i odmiennej treści", podczas gdy fałszywymi przyjaciół$m i$ badaczka nazywa "relacje semantyczno-leksykalne leksemów przynależnych do dwóch języków wywołujących powstanie błędnych ekwiwalencji". Pojęcie tytułowe pojawiło się po raz pierwszy jako Les faux-amis du traducteur i wprowadzone zostało w 1928 roku przez Maxime'a Koesslera i Julesa Derocquigny'ego w opracowaniu dotyczącym słownictwa francusko-angielskiego. Autorzy wyróżnili dwa typy fałszywych przyjació - całkowicie fałszywe (zupełnie odmienne semantycznie) oraz częściowo fałszywe (charakteryzujące się po części wspólną semantyką) (Wojan 2010: 275). Zainteresowanie leksykografów zbieżnością form graficznych słów o odmiennym brzmieniu znalazło swoje ujście po raz pierwszy w wydanej w Amsterdamie pracy Éléazara de Mauvillona z 1747 roku zatytułowanej Remarques sur les germanismes. Nieco później, bo w 1788 roku, w Salzburgu powstał szkic leksykograficzny Henriego Portitora, również dotyczący fałszywych przyjaciół na gruncie niemiecko-francuskim, pod tytułem Petit Traité des gallicismes et germanismes, dans lesquels ces deux langues sont le plus opposées l'une á l'autre. Wśród polskich uczonych pierwszą tego typu pracę napisał Franciszek Jaxyc Makulski (1795). Jego Łatwy sposób nauczania się po rosyjsku i po polsku czytać i pisać... z przydaniem... słów pod alfabetem co potrzebniejszych 
a używanych najczęściej zawierał objaśnienie niektórych słów, które w mniemaniu autora mogły być mylące dla użytkowników języka (Wojan 2010: 272).

Dziś na rynku wydawniczym dostępne są już liczne publikacje słownikowe analizujące homonimię polsko-rosyjską (Kusal 2002), polsko-białoruską (Kaleta 2014) oraz polsko-ukraińską (Karaszczuk, Prymajczok 2006). Jednak słownik poświęcony fałszywym przyjaciołom polsko-hiszpańskim dotychczas nie powstał. Zjawiska homonimii językowej nie ignorują - rzecz jasna - ogólne słowniki polsko-hiszpańskie dostępne poprzez Internet, strony poświęcone nauczaniu języka hiszpańskiego jako obcego oraz fora dla tłumaczy. Przykładem takiej witryny może być Asociación Cultural Polañoles, gdzie znajduje się krótki artykuł zatytułowany Polaco-español: falsos amigos (2015). Jednak tego rodzaju artykuły czy też dyskusje traktują zagadnienie jako ciekawostkę, a także przestrogę dla osób uczących się języka, nie wgłębiają się przy tym w klasyfikację homonimów czy próbę zbadania ich genezy.

Nie oznacza to, rzecz jasna, że tematyka homonimii polsko-hiszpańskiej została w badaniach językoznawczych całkowicie pominięta. Powstała przecież między innymi praca Edyty Waluch-de la Torre oraz Enrique'a J. Verchar García zatytułowana Propuesta metodológica y didáctica acerca del papel de los homónimos y parónimos entre español y polaco (aplicado al caso de estudiantes polacos en la aula de lengua española). Prezentuje ona problem homonimii i paronimii z punktu widzenia glottodydaktyki (w tym konkretnym przypadku analizowano proces uczenia się języka hiszpańskiego przez Polaków). Można więc tu mówić raczej o fałszywych przyjaciołach ucznia niż tłumacza, ponieważ - jak wskazują sami badacze (Waluch-de la Torre, Verchar García 2007: 480) - osoba rozpoczynająca naukę języka obcego nieświadomie wyszukuje w odbieranych komunikatach słów, które mają podobne brzmienie do słów jego języka rodzimego. Badacze proponują różne gry słowne, w tym również żarty oparte na homonimii, aby zasygnalizować uczniom istnienie tego zjawiska.

W 2012 roku w "Studiach Iberystycznych" pojawił się artykuł Gali Arias zatytułowany Diferencias léxicas entre el polaco y el español: los falsos amigos. Autorka zamieściła w nim listę słów, których podobieństwo brzmienia i pisowni mogą okazać się mylące dla osób słabo znających jeden z tych języków. Arias dzieli homonimy międzyjęzykowe na całkowite i częściowe, wskazując na zjawisko, które nazwała falsos falsos amigos ('falszywi fałszywi przyjaciele'). Tym terminem obejmuje ona pary słów, które mimo swej zbieżności formalnej nie powinny przyczyniać się do powstawania błędów, o ile osoba komunikująca się w tych językach opanowała podstawy ich obu gramatyk. Badaczka egzemplifikuje zjawisko za pomocą słowa las, które w języku polskim oznacza 'skupisko drzew', zaś w języku hiszpańskim stanowi żeński rodzajnik liczny mnogiej (Arias 2012: 23). W pracy zasygnalizowano również - o wiele powszechniejsze - zjawisko amigos fieles ('wierni przyjaciele'), polegające na współwystępowaniu identycznego znaczenia w słowach o podobnym brzmieniu (por. pl. pasażer - hiszp. pasajero, pl. idea - hiszp. idea, pl. kanibal - hiszp. caníbal) (Arias 2012: 24). 


\section{Hiszpańsko-polskie homonimy międzyjęzykowe}

Dokonując analizy zjawiska homonimii międzyjęzykowej występującej w polskim i hiszpańskim systemie językowym, posłużę się klasyfikacją stworzoną przez Małgorzatę Majewską (2002: 58), która wyróżnia: 1. wyrazy zdradliwe całkowicie i częściowo (całkowite lub częściowe różnice semantyczne), 2. wyrazy zdradliwe pod względem stylistycznym (różnią się przynależnością do różnych podsystemów stylistycznych porównywanych języków), 3. wyrazy zdradliwe pod względem gramatycznym, 4. wyrazy zdradliwe pod względem słowotwórczym. Dodatkowo chciałabym przyjrzeć się bliżej zjawisku międzyjęzykowej homonimii wewnętrznej.

Dla ułatwienia analizy większej liczby przykładów umieściłam omawiane wyrazy w tabelach, w których wyjaśniam znaczenie obu homonimów oraz - w razie potrzeby ich przynależność gramatyczną. Naturalnie nie jest to zbiór zamknięty, a niektóre przykłady mogłyby zobrazować kilka różnych odmian homonimii, ale ograniczyłam się do stosowania przykładów najbardziej reprezentatywnych dla zasygnalizowania danego zjawiska. Wszystkie definicje wyrazów polskich stworzyłam, opierając się na Słowniku języka polskiego PWN pod redakcją Witolda Doroszewskiego (wersja internetowa).

\section{Wyrazy zdradliwe całkowicie i częściowo}

Danuta Buttler (1989: 98) na podstawie porównania materiałów polskich i rosyjskich wyróżniła homonimy całkowicie zbieżne, częściowo zbieżne oraz całkowicie odmienne. Homonimy tożsame w obu językach mogą być - zdaniem badaczki - jedynie zapożyczeniami, w dodatku stosunkowo nowymi (na ogół pochodzącymi z przełomu XIX i XX wieku) i stanowiącymi często internacjonalizmy. Według definicji Buttler (1988: I) całkowite homonimy leksykalne to "wyrazy odmienne o tożsamym kształcie we wszystkich formach oraz identyczne zewnętrznie wyrazy nieodmienne, różniące się natomiast znaczeniem i pochodzeniem". Kładzie więc ona nacisk na identyczność postaci we wszystkich formach fleksyjnych, przy czym zaznacza, że w ramach języka polskiego, w odróżnieniu od języków niesłowiańskich, zasób podobnych homonimów jest niewielki (Buttler 1986: 3).

Pamiętać należy, że w przypadku fałszywych przyjaciół tłumacza podział na homonimy całkowite i częściowe nie dotyczy ich formy', lecz znaczenia. Dzieje się tak między innymi dlatego, że nie można porównywać identyczności form deklinacyjnych między językami, w których tylko jeden zakłada możliwość odmiany przez przypadki. Homonimy całkowite w poniższej analizie to wyrazy całkowicie zróżnicowane znaczeniowo, podczas gdy homonimy częściowe (niepełne) to "pary wyrazowe o rozbudowanej polisemii, których oddzielne znaczenia niekiedy pokrywają się" (Kusal, Bałaban 2014: 61).

\footnotetext{
${ }^{1}$ W przypadku wewnątrz językowej homonimii leksykalnej homonimami całkowitymi nazywamy dwa słowa, które są nie tylko identyczne formalnie, ale także ulegają identycznej odmianie przez przypadki. Whomonimii częściowej zbieżność formalna ma miejsce tylko w jednym z przypadków, np. dam 'podaruję' oraz dopełniacz od 'damy'
} 


\section{a. homonimy całkowite}

W przypadku homonimii całkowitej trudno byłoby znaleźć jakikolwiek związek pomiędzy dwoma podobnie brzmiącymi wyrazami, który mógłby wskazywać na ich wspólne pochodzenie. Podobieństwo formalne tych wyrazów wydaje się zatem zupełnie przypadkowe. Mimo podobnej wymowy grafia bywa w niektórych przypadkach odmienna z uwagi na różne systemy fonetyczne obu języków, np. dźwięk zapisywany w języku polskim za pomocą /ch/, w języku hiszpańskim zapisuje się przy pomocy /j/ (zob. tab. 1). Stąd wśród homonimów polsko-hiszpańskich trudno doszukać się tak zwanych homonimów absolutnych, czyli wyrazów zbieżnych zarówno w postaci mówionej, jak i graficznej (Buttler 1988: 3).

\section{Tab. 1. Homonimy całkowite}

\begin{tabular}{|c|c|c|c|}
\hline \multicolumn{2}{|l|}{ System języka polskiego } & \multicolumn{2}{|c|}{ System języka hiszpańskiego } \\
\hline Znaczenie leksemu & Leksem polski & Leksem hiszpański & Znaczenie leksemu \\
\hline 'pierwiastek chemiczny, gaz bezbarwny i bezwonny' & AZOT & AZOTE & 'klaps, bicz, bat' \\
\hline 'pochwała' & KOMPLEMENT & COMPLEMENTO & $\begin{array}{l}\text { 'dodatek, dopełnie- } \\
\text { nie (część zdania)' }\end{array}$ \\
\hline $\begin{array}{l}\text { 1. 'statek powietrzny bez napędu' } \\
\text { 2.' 'kopuła z materiału umieszczona nad obiektem } \\
\text { sportowym' } \\
\text { 3. 'przedmiot z cienkiej, rozciągliwej i kolorowej } \\
\text { gumy, wypełnianej powietrzem' }\end{array}$ & BALON & BALÓN & $\begin{array}{l}\text { 1.'piłka' } \\
\text { 2.'piłka nożna' } \\
\text { 3.'bańka, kolba } \\
\text { szklana' }\end{array}$ \\
\hline 'zagięcie materiału, skóry' & FAŁDA & FALDA & 'spódnica' \\
\hline 'samiec kaczki' & KACZOR & CACHORRO & 'szczeniak' \\
\hline $\begin{array}{l}\text { 1.'nasiona kawowca' } \\
\text { 2.'napój parzony z ziaren kawowca' }\end{array}$ & KAWA & CAVA & 'wino musujące' \\
\hline $\begin{array}{l}\text { 1. 'skrzynka przeznaczona do przechowywania pie- } \\
\text { niędzy' } \\
\text { 2. 'pomieszczenie, gdzie się sprzedaje bilety' } \\
\text { 3. 'urządzenie w sklepie do obliczania należności za } \\
\text { zakupiony towar' } \\
\text { 4. 'instytucja dokonująca operacji pieniężnych' } \\
\text { 5. pot. 'pieniądze' }\end{array}$ & KASA & CASA & 'dom' \\
\hline $\begin{array}{l}\text { 'nieprawidłowe funkcjonowanie organizmu lub jego } \\
\text { części' }\end{array}$ & CHOROBA & JOROBA & 'garb' \\
\hline $\begin{array}{l}\text { 'dokument będący dla banku zleceniem wypłacenia } \\
\text { określonej sumy' }\end{array}$ & CZEK & CHECO & 'Czech' \\
\hline 'szyfr' & KOD & CODO & 'łokieć' \\
\hline 'narzędzie do ścinania zboża i trawy' & KOSA & $\operatorname{COSA}$ & 'rzecz, przedmiot' \\
\hline 'ptak domowy' & KURA & CURA & 'ksiądz' \\
\hline 'tytuł zawodowy niższy niż magister' & LICENCJAT & LICENCIADO & 'magister' \\
\hline 'szkoła ponadpodstawowa' & GIMNAZJUM & GIMNASIO & $\begin{array}{l}\text { 'sala gimnastyczna, } \\
\text { siłownia' }\end{array}$ \\
\hline $\begin{array}{l}\text { 'wgłębienie między wewnętrzną stroną ramienia } \\
\text { a bokiem klatki piersiowej' }\end{array}$ & PACHA & PAJA & 'słomka' \\
\hline 'duży ptak o mieniącym się upierzeniu' & PAW & PAVO & 'indyk' \\
\hline $\begin{array}{l}\text { 1. 'błagać, domagać się' } \\
\text { 2.'nakłaniać kogoś do kontaktów seksualnych' }\end{array}$ & MOLESTOWAĆ & MOLESTAR & 'przeszkadzać' \\
\hline
\end{tabular}




\begin{tabular}{|l|l|l|l|}
\hline \multicolumn{2}{|c|}{ System języka polskiego } & \multicolumn{2}{c|}{ System języka hiszpańskiego } \\
\hline \multicolumn{1}{|c|}{ Znaczenie leksemu } & Leksem polski & Leksem hiszpański & Znaczenie leksemu \\
\hline $\begin{array}{l}\text { 1.'porozumienie' } \\
\text { 2.'odstępstwo od zasad w imię ważnych celów lub } \\
\text { dla zysku' }\end{array}$ & KOMPROMIS & COMPROMISO & $\begin{array}{l}\text { 'obietnica, zobo- } \\
\text { wiązanie' }\end{array}$ \\
\hline 'powodzenie, triumf' & SUKCES & SUCESO & 'wydarzenie' \\
\hline
\end{tabular}

Źródło: opracowanie własne.

Wśród homonimów całkowitych nie brak homografów, które są identyczne pod względem pisowni, choć należy przy tym pamiętać, że nie oznacza to bynajmniej identycznej wymowy. Między analizowanymi systemami językowymi występuje na przykład różnica w akcentowaniu wyrazów i wymowy niektórych dźwięków, w tym /s/ (zob. tab. 2).

\section{Tab. 2. Homografy}

\begin{tabular}{|c|c|c|}
\hline Znaczenie polskie & Leksem & Znaczenie hiszpańskie \\
\hline $\begin{array}{l}\text { 1. 'odgrodzone koliste miejsce w cyrku, gdzie odbywają się popisy' } \\
\text { 2. 'w starożytnym amfiteatrze: miejsce igrzysk lub przedstawień } \\
\text { teatralnych' }\end{array}$ & ARENA & 'piasek' \\
\hline 'kobieta o cechach ujemnych' & BABA & 'ślina' \\
\hline 'koszt, wartość' & CENA & 'kolacja' \\
\hline 'skóra' & CERA & 'wosk' \\
\hline 'szlak' & DROGA & 'narkotyk' \\
\hline 'przedsiębiorstwo handlowe, usługowe lub przemysłowe' & FIRMA & 'podpis' \\
\hline 'znak graficzny głoski, właściwy pismom alfabetycznym' & LITERA & 'łóżko piętrowe, kuszetka \\
\hline $\begin{array}{l}\text { 1.'wyraz twarzy' } \\
\text { 2.'ładunek wybuchowy wraz z zapalnikiem' }\end{array}$ & MINA & 'kopalnia' \\
\hline 'owad o żółto-czarnym ubarwieniu' & OSA & 'niedźwiedzica' \\
\hline $\begin{array}{l}\text { 'drzewo zakończone pióropuszem sztywnych liści, rosnące w ciepłych } \\
\text { krajach' }\end{array}$ & PALMA & 'dłoń' \\
\hline $\begin{array}{l}\text { 1. 'mężczyzna' } \\
\text { 2. 'forma grzecznościowa używana przy zwracaniu się do mężczyzny' } \\
\text { 3. 'ten, kto ma władzę nad kimś lub nad czymś' }\end{array}$ & PAN & 'chleb' \\
\hline euf.'pośladki' & PUPA & 'skaleczenie, wysypka' \\
\hline 'skaleczenie' & RANA & 'żaba' \\
\hline $\begin{array}{l}\text { 'część należności pieniężnej, płatna } \\
\text { w oznaczonym terminie' }\end{array}$ & RATA & 'szczur' \\
\hline 'wydzielina' & ROPA & 'ubranie' \\
\hline $\begin{array}{l}\text { 'kropelki wody osadzające } \\
\text { się na powierzchni gruntu, roślinach' }\end{array}$ & ROSA & 'róża, różowy' \\
\hline 'zwierzę roślinożerne o smukłym ciele i długich nogach' & SARNA & 'świerzb' \\
\hline daw.'taniec' & TAN & 'tak, taki' \\
\hline 'utwór liryczny o charakterze elegijnym, opłakujący zmarłego' & TREN & 'pociąg' \\
\hline 'tutaj, w tym miejscu' & TU & 'twój, twoja' \\
\hline
\end{tabular}

Źródło: opracowanie własne. 


\section{b. homonimy częściowe}

Homonimy tego typu posiadają co prawda różne znaczenia, ale oba słowa mają wyraźnie wspólną etymologię. W przypadku takiej homonimii zwodnicze bywają próby "domyślenia się" znaczenia pewnych wyrazów na podstawie dotychczasowego doświadczenia językowego. Użytkownik zauważa pewne analogie między językami, dzięki czemu łatwiej przyswaja nową leksykę. Jeśli zauważa, że hiszpańskie información to informacja, a comunicación to komunikacja, bierze za pewnik, że większość słów kończących się w języku hiszpańskim członem -ción będzie miała swój odpowiednik w języku polskim, który zakończy się na -cja. Zasada ta sprawdzi się w wielu przypadkach: motivación ('motywacja'), abdicación ('abdykacja'), separación ('separacja') itd. Jednak mechaniczne tworzenie i rozumienie słów w ten sposób może prowadzić do poważnych błędów. Hiszpańskie ubicación Polak z rozmachu przetłumaczy jako ubikację, podczas gdy oznacza ono 'położenie, ulokowanie'. Różnica ta nie jest jednak przypadkowa i wskazuje na wspólne korzenie obu słów, mianowicie łacińskie słowo ubique oznaczające 'wszędzie'. Od niego powstało niemieckie Ubication 'zajmowanie jakiejś przestrzeni, lokalizacja', hiszpańskie ubicar, czyli umieszczać, oraz staropolskie ubikacja w znaczeniu 'pokój, izba, pomieszczenie', przy czym w procesie ewolucji języka znaczenie tego słowa zawęziło się z czasem do pomieszczenia bardzo konkretnego, służącego tylko do załatwiania potrzeb fizjologicznych. Podobnie słowo pensión nie oznacza wcale pensji ('wynagrodzenie, zarobek'), tylko 'rentę, emeryturę', a w obu językach pojawiło się zapewne za pośrednictwem języka francuskiego, w którym znaczenie słowo pension oznacza 'rentę, alimenty'.

Ciekawym przykładem homonimów częściowych są słowa, które mają tę samą etymologię i występują do dziś w podobnym znaczeniu, przy czym w jednym $z$ języków jest to określenie szersze, a w drugim węższe. Przykładem takiego homonimu jest wyraz bandera, który w języku hiszpańskim oznacza flagę (każdego rodzaju, w tym również państwową), a w języku polskim jedynie flagę wskazującą na przynależność państwową statku. Podobnie jest z hiszpańskim słowem bar$c a$, które oznacza łódź, podczas gdy polska barka to "statek przeznaczony do przewozu towarów na śródlądowych drogach wodnych, zalewach i w portach" ${ }^{\prime 2}$, jest to zatem jednostka pływająca spełniająca bardzo określoną funkcję (zob. tab.3).

Tab. 3. Homonimy częściowe

\begin{tabular}{|l|l|l|l|}
\hline \multicolumn{1}{|c|}{ Znaczenie w języku polskim } & Leksem polski & Leksem hiszpański & \multicolumn{1}{|c|}{$\begin{array}{c}\text { Znaczenie w języku } \\
\text { hiszpańskim }\end{array}$} \\
\hline 'toaleta' & UBIKACJA & UBICACIÓN & 'położenie, ulokowanie' \\
\hline 'wypłata' & PENSJA & PENSIÓN & 'renta, emerytura' \\
\hline 'flaga na statku' & BANDERA & BANDERA & 'flaga' \\
\hline 'statek przeznaczony do przewozu towarów' & BARKA & BARCA & 'łódź' \\
\hline
\end{tabular}

Źródło: opracowanie własne.

${ }^{2}$ Definicja przytoczona z internetowego Słownika języka polskiego PWN, dostępnego pod adresem: sjp.pwn. pl [dostęp: 6 marca 2017]. 


\section{Wyrazy zdradliwe pod względem stylistycznym}

Do tego rodzaju homonimów zaliczamy wyrazy, które mają nie tylko podobne brzmienie i pisownię, ale również znaczenie, pochodzą jednakże z innych rejestrów. Pewne wyrazy mogą mieć w jednym języku charakter neutralny, a w drugim stanowić archaizm, określenie potoczne, żartobliwe lub książkowe. Niepoprawne odczytanie tego rejestru nie stanowi wprawdzie bariery komunikacyjnej, ale może zdezorientować rozmówcę, dla którego dane określenie wydaje się np. wulgarne, podczas gdy dla mówiącego jest ono słowem pozbawionym takiego nacechowania.

Na gruncie języka polskiego i hiszpańskiego takich słów nie jest wiele i zazwyczaj pojawiły się one w obu językach jako zapożyczenia. Na przykład hiszpański przymiotnik contento oraz polski kontent pochodzą z języka francuskiego (content 'zadowolony, usatysfakcjonowany') i nie zmieniły swojego znaczenia, jednak w języku hiszpańskim występuje on jako słowo neutralne, a w języku polskim postrzegane jest jako wyraz dawny i używa się go rzadko (zob. tab. 4).

\section{Tab. 4. Homonimy stylistyczne}

\begin{tabular}{|l|l|l|l|l|}
\hline \multicolumn{1}{|c|}{$\begin{array}{c}\text { Rodzaj rejestru } \\
\text { w języku polskim }\end{array}$} & \multicolumn{1}{|c|}{ Leksem polski } & \multicolumn{1}{c|}{$\begin{array}{c}\text { Znaczenie } \\
\text { w obu językach }\end{array}$} & $\begin{array}{c}\text { Leksem } \\
\text { hiszpański }\end{array}$ & $\begin{array}{c}\text { Rodzaj rejestru } \\
\text { w języku hiszpańskim }\end{array}$ \\
\hline dawny & KONTENT & 'zadowolony' & CONTENTO & neutralny \\
\hline archaiczny & BATAĆ & 'uderzać' & BATIR & neutralny \\
\hline potoczny/pogardliwy & BANDA & 'grupa ludzi' & BANDA & neutralny \\
\hline archaiczny & CEBER & 'pojemnik, wiadro' & CEBERO & regionalny (Murcia) \\
\hline archaiczny & $\begin{array}{l}\text { LUTO } \\
\text { (w wyrażeniu: luto mi jest) } \\
\text { lub LUTOŚĆ }\end{array}$ & 'żałoba, cierpienie' & LUTO & neutralny \\
\hline archaiczny & LUNA & 'księżyc' & LUNA & neutralny \\
\hline archaiczny & MARMELADA & 'marmolada, kon- & MARMELADA & neutralny \\
fitura' & 'wnuk' & NIETO & neutralny \\
\hline archaiczny & NIEĆ & 'szczur' & RATA & neutralny \\
\hline archaiczny & RATEW & 'zadowolony' & CONTENTO & neutralny \\
\hline dawny & KONTENT & & & \\
\hline
\end{tabular}

Źródło: opracowanie własne

\section{Wyrazy zdradliwe pod względem gramatycznym}

Do homonimów gramatycznych zaliczyć można między innymi słowa o identycznym brzmieniu, ale należące do różnych części mowy (zob. tab. 5).

Niektóre słowa z tej grupy mogą być homonimiczne również wewnątrzjęzykowo, co sprawia, że w jednym ze znaczeń międzyjęzykowa homonimia gramatyczna wystąpi, a w drugim już nie (zob. tab. 6). 
Tab. 5. Homonimy gramatyczne

\begin{tabular}{|c|c|c|c|c|c|}
\hline Część mowy & Znaczenie w języku polskim & $\begin{array}{c}\text { Leksem } \\
\text { polski }\end{array}$ & $\begin{array}{c}\text { Leksem } \\
\text { hiszpański }\end{array}$ & $\begin{array}{c}\text { Znaczenie w języ- } \\
\text { ku hiszpańskim }\end{array}$ & Część mowy \\
\hline rzeczownik & $\begin{array}{l}\text { 1. pogard. 'o człowieku ograniczonym, } \\
\text { głupim' } \\
\text { 2. daw. 'osoba upośledzona umysłowo' }\end{array}$ & DEBIL & DÉBIL & 'słaby' & przymiotnik \\
\hline rzeczownik & 'brak towaru lub pieniędzy' & MANKO & MANCO & $\begin{array}{l}\text { 1. 'jednoręki' } \\
\text { 2. 'wadliwy, nie- } \\
\text { kompletny' }\end{array}$ & przymiotnik \\
\hline przymiotnik & $\begin{array}{l}\text { 1.'taka, której brzeg tnie' } \\
\text { 2.'pikantna' }\end{array}$ & OSTRA & OSTRA & 'ostryga' & rzeczownik \\
\hline rzeczownik & $\begin{array}{l}\text { 1. 'dwójka, duet' } \\
\text { 2.'woda w stanie gazowym' }\end{array}$ & PARA & PARA & 'żeby' & spójnik \\
\hline rzeczownik & 'roślina warzywna o długiej, białej cebulce' & POR & POR & 'przez, podczas' & przyimek \\
\hline
\end{tabular}

Źródło: opracowanie własne.

Tab. 6. Homonimia gramatyczna ujawniająca się w zjawisku homonimii homonimów

\begin{tabular}{|l|l|l|l|l|l|}
\hline Część mowy & \multicolumn{1}{|c|}{ Znaczenie w języku polskim } & $\begin{array}{c}\text { Leksem } \\
\text { polski }\end{array}$ & $\begin{array}{c}\text { Leksem } \\
\text { hiszpański }\end{array}$ & $\begin{array}{l}\text { Znaczenie w języ- } \\
\text { ku hiszpańskim }\end{array}$ & Część mowy \\
\hline rzeczownik & $\begin{array}{l}\text { 'produkt spożywczy otrzymywany } \\
\text { z mleka' }\end{array}$ & SER & SER & $\begin{array}{l}\text { 1. 'być, istnieć' } \\
\text { 2. 'byt, istota' }\end{array}$ & $\begin{array}{l}\text { 1. czasownik } \\
\text { 2. rzeczownik }\end{array}$ \\
\hline rzeczownik & 'napój alkoholowy z winogron' & WINO & VINO & $\begin{array}{l}\text { 1.'przyszedł' } \\
\text { 2.'wino' }\end{array}$ & $\begin{array}{l}\text { 1. czasownik } \\
\text { (w trzeciej } \\
\text { osobie w cza- } \\
\text { sie przeszłym) } \\
\text { 2. rzeczownik }\end{array}$ \\
\hline
\end{tabular}

Źródło: opracowanie własne.

Homonimy gramatyczne mogą również należeć do tej samej części mowy, ale występować w innej liczbie. Przykładem obrazującym ten rodzaj homonimii są zazwyczaj polskie słowa, które w liczbie pojedynczej kończą się na -s, ponieważ w języku hiszpańskim sufiks -s/-es tworzy liczbę mnogą rzeczowników i przymiotników zob. tab. 7).

Tab. 7. Homonimia gramatyczna - odmienność liczby gramatycznej

\begin{tabular}{|c|l|l|l|l|}
\hline Liczba & Znaczenie w języku polskim & \multicolumn{1}{|c|}{ Leksem } & Znaczenie w języku hiszpańskim & \multicolumn{1}{c|}{ Liczba } \\
\hline pojedyncza & $\begin{array}{l}\text { 'zwierzę domowe' } \\
\text { (liczba mnoga: } p \text { sy) }\end{array}$ & PIES & $\begin{array}{l}\text { 'stopy' } \\
\text { (liczba pojedyncza: } \text { pie) })\end{array}$ & mnoga \\
\hline pojedyncza & $\begin{array}{l}\text { 'muszla klozetowa' } \\
\text { (liczba mnoga: sedesy) }\end{array}$ & SEDES & $\begin{array}{l}\text { 'siedziby' } \\
\text { (liczba pojedyncza: sede) }\end{array}$ & mnoga \\
\hline
\end{tabular}

Źródło: opracowanie własne.

Niektóre rzeczowniki, chociaż posiadają to samo znaczenie w obu językach i reprezentują tę samą część mowy w tej samej liczbie, kwalifikują się jako homonimy gramatyczne, ponieważ są zwodnicze pod względem rodzaju. I polski, i hiszpański system językowy posiada rodzaje gramatyczne, przy czym ich przynależność do poszczególnych rzeczowników nie rozkłada się w obu językach identycznie. Przede wszystkim 
w języku hiszpańskim rodzaj jest sygnalizowany przez rodzajnik, którego w języku polskim nie ma. Drugą istotną różnicą jest brak w języku hiszpańskim rodzaju nijakiego. Rodzaj gramatyczny wielu rzeczowników jest dla użytkowników obu języków dość logiczny (rzeczowniki żeńskie określają kobietę, dziewczynę, samicę, a męskie mężczyznę, chłopca i samca). Ponadto w obu językach rzeczowniki rodzaju żeńskiego kończą się zazwyczaj literą - a (polskie: brama, lampa, kocica, hiszpańskie: (la) puerta, lámpara, gata). Jednak w przypadku rzeczowników nieosobowych rodzajnik nie zawsze bywa oczywisty i nie zawsze jest zgodny z powyższą regułą (zob. tab. 8).

Tab. 8. Homonimia gramatyczna - odmienny rodzaj gramatyczny

\begin{tabular}{|l|l|l|}
\hline \multicolumn{1}{|c|}{ Rodzaj w języku polskim } & \multicolumn{1}{|c|}{ Leksem } & \multicolumn{1}{|c|}{ Rodzaj w języku hiszpańskim } \\
\hline żeński & $\begin{array}{l}\text { MAPA } \\
\text { 'plan terenu' }\end{array}$ & męski (el mapa) \\
\hline żeński & $\begin{array}{l}\text { PLANETA } \\
\text { 'ciało niebieskie' }\end{array}$ & męski (el planeta) \\
\hline
\end{tabular}

Źródło: opracowanie własne.

\section{Wyrazy zdradliwe pod względem słowotwórczym}

Powodem homonimii słowotwórczej mogą być afiksy bądź formacje powstałe w drodze podobnych zabiegów derywacyjnych (Karaszczuk, Pryjmaczok 2006: 163). Pod tym względem zwodniczy okazuje się przykład z polskim słowem kryminalista i łudząco do niego podobnym hiszpańskim criminalista. Oba leksemy powstały wskutek identycznych procesów słowotwórczych, sufiks -ista jest bowiem wykorzystywany w obu językach do tworzenia nazw osób i wiele słów powstałych w podobny sposób ma identyczne brzmienie i znaczenie zarówno w języku polskim, jak i hiszpańskim (np. filatelista, futbolista itd.). Wyraz omawiany zawiera również łaciński człon crimen 'przestępstwo', który w obu językach rozumiany jest tak samo. Jednak - na nieszczęście dla niewprawnego tłumacza - występuje tu zjawisko enantiosemii - jedno słowo oznacza przestępcę, a drugie osobę, która przestępcę ściga, są to więc słowa o powiązanych wprawdzie ze sobą, lecz skrajnie odmiennych znaczeniach (zob. tab. 9).

Tab. 9. Homonimia słowotwórcza

\begin{tabular}{|l|l|l|l|}
\hline Znaczenie w języku polskim & \multicolumn{1}{|c|}{ Leksem polski } & Leksem hiszpański & Znaczenie w języku hiszpańskim \\
\hline 'przestępca' & KRYMINALISTA & CRIMINALISTA & 'kryminalistyk' \\
\hline 'wodotrysk' & FONTANNA & FONTANA & 'źródło' \\
\hline 'osobliwy, dziwaczny' & KURIOZALNY & CURIOSO & 'ciekawy, wścibski' \\
\hline
\end{tabular}

Źródło: opracowanie własne. 


\section{Międzyjęzykowa homonimia wewnętrzna}

Pomiędzy analizowanymi przeze mnie systemami językowymi występuje również zjawisko międzyjęzykowej homonimii wewnętrznej. Stanowi ona specyficzny rodzaj homonimii, który znajduje się zazwyczaj na pograniczu badań nad fałszywymi przyjaciółmi. Analizowane leksemy są jednocześnie homonimami międzyjęzykowymi i wewnątrzjęzykowymi. Mamy tu zatem do czynienia z homonimią na dwóch poziomach wewnątrz danego języka oraz w relacji z innym językiem. Na szczęście dla mówiącego niektóre ze znaczeń określonego słowa pokrywają się, jednak założenie, że pokrywać się będą wszystkie jego znaczenia, może okazać się zwodnicze. Zjawisko międzyjęzykowej homonimii wewnętrznej występuje przy słowach przejętych z języków obcych, stąd możliwość ich podobieństwa semantycznego w niektórych aspektach.

Na bazie wspomnianej wcześniej reguły słowotwórczej, szukając słowa racja w znaczeniu 'rozum, rozsądek', osoba polskojęzyczna może stworzyć na poczekaniu słowo ración, które wprawdzie istnieje w języku hiszpańskim, ale tylko w znaczeniu porcji, racji żywnościowej. Poszukiwane przez Polaka słowo to razón 'rozum, racja'. Słowo racja posiada więc $w$ języku polskim oba przedstawione znaczenia, a hiszpańskie ración ma tylko jedno z nich. Podobnie dzieje się w przypadku słów kontakt i contacto (zob. tab. 10). Myśląc o kontakcie jako 'gniazdku elektrycznym', Polak powinien posłużyć się słowem enchufe.

\section{Tab. 10. Międzyjęzykowa homonimia wewnętrzna}

\begin{tabular}{|l|l|l|l|c|}
\hline Znaczenie dodatkowe & \multicolumn{1}{|c|}{ Język polski } & \multicolumn{1}{|c|}{ Znaczenie wspólne } & Język hiszpański & Znaczenie dodatkowe \\
\hline 'rozum, rozsądek' & RACJA & 'porcja, racja żywnościowa' & RACIÓN & - \\
\hline 'gniazdko elektryczne' & KONTAKT & 'relacja interpersonalna' & CONTACTO & - \\
\hline 1. 'kawałek papieru & KARTA & 1. 'kartonik służący do gry' & CARTA & 'list' \\
z nadrukiem' & & 2.'menu, jadłospis' & & \\
2. 'kartka, strona' & & & & \\
\hline
\end{tabular}

Źródło: opracowanie własne.

\section{Wnioski}

Język polski i hiszpański, choć należą do różnych rodzin językowych, posiadają wiele elementów leksykalnych o identycznym lub podobnym brzmieniu, a niekiedy również o pokrywającym się częściowo znaczeniu, ze względu na wspólne zapożyczenia między innymi z łaciny, języka włoskiego oraz francuskiego. Wystarczy przywołać tu takie przykłady z języka hiszpańskiego jak triunfo (pl. 'triumf', słowo pochodzące z łaciny), carroza (pl. 'karoca', słowo pochodzenia włoskiego) czy maquillaje (pl. 'makijaż', słowo pochodzenia francuskiego). Niejednokrotnie reguły słowotwórcze obu języków pokrywają się do tego stopnia, że pewne terminy można tworzyć i rozumieć intuicyjnie (tak było choćby w przypadku słów z zakończeniem na -ción/-cja czy -ista). Jednak ich automatyczne tłumaczenie niepoparte wiedzą językową może 
skutkować poważnymi pomyłkami i nieporozumieniami, ponieważ znaczenia słów, ich forma gramatyczna oraz nacechowanie emocjonalne mogą być w obu językach skrajnie odmienne. Chociaż wiele słów języka polskiego i hiszpańskiego ma wspólne pochodzenie, co z pewnością ułatwia komunikację międzynarodową, pamiętać należy, że podobieństwo brzmieniowe słów nie zawsze wynika z ich etymologii. Przypadkowa zbieżność formalna, która występuje w większości spośród analizowanych przykładów falsos amigos, nie pociąga za sobą innych podobieństw - w znaczeniu, przypisaniu do określonego rodzaju lub liczby gramatycznej.

\section{Literatura}

Arias G., 2012, Diferencias léxicas entre el polaco y el español: los falsos amigos, "Studia Iberystyczne” nr 11.

Buttler D., 1986, Mały słownik homonimów polskich dla cudzoziemców, Warszawa: Wydawnictwa Uniwersytetu Warszawskiego.

Buttler D., 1988, Słownik polskich homonimów całkowitych, Wrocław: Zakład Narodowy im. Ossolińskich - Wydawnictwo PAN.

Buttler D., 1989, Polskie i rosyjskie homonimy rzeczownikowe [w:] Paralele w rozwoju słownictwa języków słowiańskich, red. H. Popowska-Taborska, Wrocław: Zakład Narodowy im. Ossolińskich.

Głowiński M. et al., 1993, Podręczny słownik terminów literackich, Warszawa: Open.

Kaleta R., 2014, Białorusko-polska homonimia międzyjęzykowa, Warszawa: Slawistyczny Ośrodek Wydawniczy Instytutu Slawistyki Polskiej Akademii Nauk.

Kusal K., 2002, Rosyjsko-polski słownik homonimów międzyjęzykowych, Wrocław: Wydawnictwo Uniwersytetu Wrocławskiego.

Kusal K., Bałaban K., 2014, Rosyjsko-polska homonimia międzyjęzykowa jako problem leksykograficzny , „Anuari de Filologia.Llengües i Literatures Modernes”, nr 4

Karaszczuk H., Prymajczok O., 2006, Homonimia międzyjęzykowa (ukraińsko-polska), „Annales Universitatis Mariae Curie-Skłodowska Lublin - Polonia", t. 24.

Rudolf K.F., 2003, Słownik angielsko-polski polsko-angielski wyrazów zdradliwych, Kraków: Wydawnictwo Literackie.

Rudolf K.F., 2004, Słownik wyrazów pułapek. Język angielski, Kraków: Wydawnictwo Literackie.

Majewska M., 2002, Homonimia i homonimy w opisie językoznawczym, Warszawa: Elipsa.

Waluch-de la Torre E., Verchar García E. J., 2007, Propuesta metodológica y didáctica acerca del papel de los homónimos y parónimos entre español y polaco (aplicado al caso de estudiantes polacos en la aula de lengua española) [w:] Actas del I Congreso Internacional de Lengua, Literatura y Cultura Española: la Didáctica de la enseñanza para extranjeros, Onda: JMC.

Wojan K., 2005, Międzyjęzykowa homonimia leksykalna. Zagadnienia analizy [w:] Język a rzeczywistość. Rusycystyczne studia konfrontatywne, red. P. Czerwiński, H. Fontański, Katowice: Wydawnictwo Naukowe Śląsk.

Wojan K., 2010, Wstęp do badań wieloznaczności leksemów w ujęciu kontrastywnym, Gdańsk: Wydawnictwo Uniwersytetu Gdańskiego. 


\section{Źródłla leksykograficzne}

Krupa A. (red.), 1999, Encyklopedia popularna PWN, wyd. 29 zm. i uzup., Warszawa: Wydawnictwo Naukowe PWN.

Internetowa Poradnia językowa dra Macieja Malinowskiego, 2017, http://obcyjezykpolski.pl/ [dostęp: 9.03].

Internetowy słownik języka hiszpańskiego stworzony przez Real Academia Española, 2017, http:// dle.rae.es/ [dostęp: 9.03].

Oficjalna strona Asociación Cultural Salmantino-Polaca „Polañoles", 2017, http://www.asociacionculturalpolanoles.org/es/blog/polaco-espa\%C3\%B1ol-falsos-amigos [dostęp: 9.05].

Doroszewski W. (red.), 1958-1969, Słownik języka polskiego, Warszawa: Państwowe Wydawnictwo Naukowe, https://sjp.pwn.pl/doroszewski/ [dostęp: 9.03.2017]. 